Syntax Literate : Jurnal Ilmiah Indonesia p-ISSN: 2541-0849

e-ISSN : 2548-1398

Vol. 6, No. 3, Maret 2021

\title{
ANALISIS TINGKAT ORGANIZATIONAL CITIZENSHIP BEHAVIOUR PADA KARYAWAN BEST WESTERN PREMIER LA GRANDE HOTEL BANDUNG
}

Fernando Samuel Manurung, Dwike Rizky Andadari dan Ruddy Agus Kurniawan

Universitas Kristen Maranatha Bandung Jawa Barat, Indonesia

Email: fernandosamuelmanurung@gmail.com,dwikerizky@gmail.com dan

ruddyagusk@gmail.com

\section{Abstract}

The research aims to make an understanding of Organizational Citizenship Behaviour (OCB) in Best Western Premier La Grande Hotel Bandung by using quantitative methods. Data collection the technique used was spreading questionnaires to 60 respondents (random sampling). Based on the research that has been done to the employee, Organizational Citizenship Behavior showed very high scores and the highest score was Courtesy Dimension. The hotel need to keep the OCB high to also keep the Company productivity high.

Keywords: organizational citizenship behaviour (OCB); employee; hotel

\begin{abstract}
Abstrak
Penelitian ini bertujuan untuk mengetahui tingkat Organizational Citizenship Behaviour (OCB) di Best Western Premier La Grande Hotel Bandung dengan menggunakan metode kuantitatif. Teknik pengumpulan data adalah survei menggunakan kuesioner yang dibagikan ke 60 responden random sampling. Berdasarkan hasil penelitian yang telah dilakukan kepada karyawan menunjukan bahwa tingkat Organizational Citizenship Behavior karyawan hotel tersebut sangat tinggi dengan skor rata-rata tertinggi pada dimensi Courtesy. Hal tersebut harus tetap dijaga karena semakin tinggi tingkat Organizational Citizenship Behavior karyawan, akan berdampak semakin tinggi pula produktivitas perusahaan.
\end{abstract}

Kata kunci: Perilaku OCB; karyawan; hotel

Coresponden Author

Email: fernandosamuelmanurung@gmail.com Artikel dengan akses terbuka dibawah lisensi

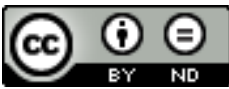

\section{Pendahuluan}

Setiap negara memiliki potensi yang sangat besar dalam sektor pariwisata. Begitu pula di Indonesia, sektor pariwisata merupakan salah satu penyumbang devisa terbesar bagi negara Indonesia. Beberapa daerah di Indonesia menjadi tujuan wisata yang cukup menarik bagi wisatawan lokal maupun mancanegara dan Kota bandung adalah salah 
satunya. (Fitriyana, 2015) mengatakan bahwa Bandung adalah salah satu daerah wisata di Indonesia yang memiliki banyak daya tarik wisata. Jumlah wisatawan Kota Bandung meningkat dari tahun ke tahun. Peningkatan wisatawan ke Kota Bandung berbanding lurus dengan peningkatan kegiatan wisata di Kota Bandung. Industri pariwisata terdiri dari berbagai sub sektor seperti hotel, perdagangan perjalanan, maskapai penerbangan, kapal pesiar, kereta api dan sebagainya (George \& Joseph, 2015). Perhotelan merupakan salah satu faktor yang paling berpengaruh mendukung kemajuan bidang pariwisata (Hemaloshinee \& Nomahaza, 2017). Hal tersebut terlihat dari jumlah hotel di Kota Bandung yang terus meningkat setiap tahunnya, (Maywaty, (2019)). Berikut gambaran peningkatan hotel di Kota Bandung.

Tabel 1

Hotel Berbintang Kota Bandung

\begin{tabular}{cc}
\hline Tahun & $\begin{array}{c}\text { Jumlah Hotel } \\
\text { Berbintang }\end{array}$ \\
\hline 2015 & 112 \\
\hline 2016 & 118 \\
\hline 2017 & 127 \\
\hline 2018 & 288 \\
\hline
\end{tabular}

Sumber: TA Maywati (2019) - telah diolah kembali oleh Penulis

Dampak dari jumlah hotel yang meningkat adalah persaingan dari binsis perhotelan itu sendiri. Kualitas pelayanan menjadi faktor penting dalam organisasi layanan untuk menghadapi persaingan, (Dominic, Goh, Wong, \& Chen, 2010). Kualitas pelayanan bergantung pada bagaimana karyawan melayani tamu (Abtahi, 2014). Maka setiap hotel harus berusaha untuk memiliki dan menjaga kualitas pekerjaan dari setiap karyawanannya. Telah dibahas dalam berbagai literatur dan penelitian bahwa sumber daya manusia atau karyawan merupakan salah satu faktor penting yang menentukan keberhasilan suatu organisasi (Pradana, Fakhri, Gilang, \& Khairin, 2018). Karyawan diharapkan dapat berkotribusi dan bekerja sesuai dengan standar yang dimiliki oleh perusahaan. Namun, beberapa penelitian mengatakan bahwa kualitas kinerja dapat dikatakan baik ketika karyawan bukan hanya dapat menyelesaikan pekerjaaan pokoknya (in-role) namun juga pekerjaan di luar pekerjaan pokoknya (extra-role). Perilaku (extrarole) bagi karyawan yang memiliki kontak langsung dengan pelanggan atau tamu dapat mempengaruhi penilaian tentang kualitas pelayanan hotel tersebut, (Ratnayaka, Kumara, \& Silva, 2020). Perilaku di luar pekerjaan pokok disebut dengan Organizational Citizenship Behaviour (OCB). (Sanusi, Ariana, \& Ariani, 2018) mengatakan bahwa perilaku OCB dapat meningkatkan kinerja sebuah organisasi atau perusahaan. Hal tersebut membuktikan bahwa perilaky OCB perlu diperhatikan dan dijaga keberadaannya di sebuah perusahaan.

Menurut (Triyanto, 2009) menyebutkan bahwa OCB merupakan perilaku membangun dan positif dan dilakukan secara sukarela untuk mendukung dan berkontribusi pada pekerjaan rekan kerja yang secara otomatis memberikan manfaat 
bagi perusahaan karena meningkatkan produktivitas dan efisiensi dalam organisasi. (Singh \& Singh, 2010) dalam penelitiannya mengutip bahwa OCB merupakan perilaku yang fungsional, extra-role, prososial yang mengarahkan individu, kelompok atau organisasi.

Menurut (Moorhead \& Griffin, 2013), Organizational Citizenship (keanggotaan organisasi) adalah perilaku individu yang memberikan kontribusi keseluruhan yang positif kepada organisasi. Organizational Citizenship Behavior (OCB) adalah perilaku pilihan yang tidak menjadi bagian dari kewajiban kerja formal, namun mendukung berfungsinya organisasi tersebut secara efektif, (Robbins, 2015). Menurut (Olowookere \& Adejuwon, 2015), Organizational Citizenship Behavior (OCB) adalah kontribusi pekerja "diatas dan lebih dari" deskripsi kerja formal. Dapat diartikan bahwa Organizational Citizenship Behavior (OCB) melibatkan beberapa hal perilaku yang meliputi perilaku menolong orang lain, menjadi sukarelawan untuk tugas-tugas tambahan, mematuhi aturan aturan dan prosedur-prosedur ditempat kerja.

Dari beberapa pendapat ahli diatas dapat disimpulkan bahwa Organizational Citizenship Behavior (OCB) merupakan perilaku yang dilakukan individu tetapi perilaku tersebut sebenarnya bukan merupakan keharusan atau kewajibannya. Selain itu Organizational Citizenship Behavior (OCB) merupakan perilaku kesetiakawanan sosial bersifat sukarela, seperti membantu rekan kerja dalam menyelesaikan pekerjaan, memberi bantuan pada karyawan baru, tidak istirahat ataupun cuti jika tidak diperlukan dan perilaku sukarela untuk mengerjakan sesuatu pekerjaan meskipun diluar deskripsi pekerjaanya, (Husniati \& Pangestuti, 2019).

Dengan demikian, OCB menjadi penting dan esensial bagi sebuah organisasi karena membantu mencapai tujuan organisasi dan meningkatkan perilaku organisasi. Begitu pula, pada industri perhotelan, diharapkan setiap hotel memiliki karyawan yang berperilaku OCB tinggi. Jadi, manajemen hotel perlu memikirkan seberapa besar atau tinggi perilaku OCB pada pekerjaan karyawan di hotelnya dan terus berusaha untuk dapat menghasilkan karyawan - karyawan yang memiliki kerelaan hati untuk bekerja diluar pekerjaan pokoknya. Penelitian terkait dengan OCB ini dirasa penting untuk dilakukan karena karyawan hotel merupakan salah satu pekerjaan di bidang jasa yang cukup banyak mempekerjakan karyawan kontrak dibanding dengan karyawan tetap. OCB juga memberikan dampak yang positif bagi perusahaan dalam meningkatkan kinerja karyawan, kepuasan pelanggan, dan mendukung pencapaian tujuan organisasi. Penelitian ini diharapkan dapat memberikan sumbangan informasi dan menambah informasi yang sudah ada dalam pengelolaan SDM di hotel, khususnya pada dimensi OCB yang terdiri dari altruism, courtesy, sportsmanship, conscientiousness and civic virtue, (Tambe et al, (2014), pada karyawan hotel.

Penelitian terdahulu yang dilakukan oleh Sanusi, A. C., Ariana, N. \& Ariani, N dengan penelitian yang berjudul Tingkat organizational citizenship behavior (ocb) karyawan di four points seminyak. Jurnal Kepariwisataan Dan Hospitalitas. Hal yang membedakan penelitian ini dengan penelitian lain bahwa penelitian ini tidak berfokus pada hal buruk yang terjadi di hotel sebagai tempat dilakukan penelitian, namun 
berfokus pada hal positif yang membantu hotel untuk meningkatkan kinerja karyawan, kepuasan pelanggan, dan mendukung pencapaian tujuan organisasi. Manfaat dari penelitian ini untuk mengetahui tingkat OCB di Hotel Best Western Premier La Grande Bandung yang akan menjadi informasi penting yang membantu pengelolaan SDM di hotel untuk meningkatkan kinerja karyawan, kepuasan pelanggan, dan mendukung pencapaian tujuan organisasi.

\section{Metode Penelitian}

Penelitian ini menggunakan metode penelitian kuantitatif yang memiliki landasan filsafat positivism dan digunakan untuk meneliti teori sebelumnya dengan populasi dan sampel tertentu. Pengumpulan data menggunakan instrumen penelitian dengan menggunakan analisis data yang bersifat kuantitatif/statistik dengan tujuan untuk membuktikan atau menguji hipotesis yang telah ditetapkan (Sugiyono, 2015). Untuk mendapatkan data yang dibutuhkan, penulis menggunakan metode survei dengan teknik pengumpulan data dengan pengamatan kuesioner dan hasil penelitian cenderung untuk digeneralisasikan. Responden dipilih pengambilan sampel acak. Sampel pada penelitian ini adalah sebanyak 60 orang dari pegawai Hotel Best Western Premier La Grande Bandung.

\section{Hasil dan Pembahasan}

Peneliti menyebarkan kuesioner untuk mengukur Altruism, Conscientiousness, Sportmanship, Civic Virtue, dan Courtesy yang merupakan dari dimensi pada Organizational Citizenship Behaviour

Tabel 2

Posisi Indikator Organizational Citizenship Behaviour

\begin{tabular}{cc}
\hline Skor Rataan & Keterangan \\
\hline $1,0-1,8$ & Sangat Rendah \\
\hline $1,81-2,6$ & Rendah \\
\hline $2,61-3,4$ & Sedang \\
\hline $3,41-4,2$ & Tinggi \\
\hline $4,21-5,0$ & Sangat Tinggi \\
\hline Sumber: (Sugiyono, 2013) \& Hasil Pengolahan Data
\end{tabular}

Tabel di atas adalah pengkategorian skor dari jumlah penilaian indikator pada kuesioner yang telah dibagikan kepada responden.Tabel di tas didapatkan setelah melakukan penghitungan nilai indeks minimum, nilai indeks maksimum, interval dan jarak interval. Jarak interval didapatkan sebesar 0,80. Dari data tabel di atas, jika didapatkan skor rataan di antara 1,00 - 1,80 maka indikator tersebut berada dalam kategori sangat rendah, jika didapatkan skor rataan di antara 1,81 - 2,60 maka indikator tersebut berada dalam kategori rendah, jika didapatkan skor rataan di antara 2,61 - 3,40 maka indikator tersebut berada dalam kategori sedang, jika didapatkan skor rataan di antara 3,41 - 4,20 maka indikator tersebut berada dalam kategori tinggi dan jika 
didapatkan skor rataan di antara 4,21 - 5,00 maka indikator tersebut berada dalam kategori sangat tinggi.

1. Tingkat Altruism Karyawan Hotel Best Western Premier La Grande Bandung

Tabel 3

Tingkat Altruism

\begin{tabular}{lc}
\hline Indikator Altruism & Rata - Rata \\
\hline Menggantikan rekan kerja yang tidak masuk atau istirahat & 4.43 \\
\hline Membantu orang lain yang pekerjaannya overload & 4.45 \\
\hline $\begin{array}{l}\text { Membantu proses orientasi karyawan baru meskipun tidak } \\
\text { diminta }\end{array}$ & 4.22 \\
\hline $\begin{array}{l}\text { Membantu mengerjakan tugas orang lain pada saat mereka } \\
\text { tidak masuk }\end{array}$ & 4.07 \\
\hline $\begin{array}{l}\text { Meluangkan waktu untuk membantu orang lain berkaitan } \\
\text { dengan permasalahan-permasalahan pekerjaan }\end{array}$ & 4.28 \\
\hline $\begin{array}{l}\text { Menjadi volunteer untuk mengerjakan sesuatu tanpa diminta } \\
\text { Membantu orang lain di luar departemen ketika mereka }\end{array}$ & 4.03 \\
\hline $\begin{array}{l}\text { Bersedia ditempatkan untuk berkerja di departemen lain saat } \\
\text { dibutuhkan }\end{array}$ & 4.01 \\
\hline $\begin{array}{l}\text { Membantu pelanggan dan para tamu jika mereka } \\
\text { membutuhkan bantuan }\end{array}$ & 4.82 \\
\hline
\end{tabular}

\begin{tabular}{cc}
\hline Total Altruism & 4.25 \\
\hline Sumber: Hasil Pengolahan Data
\end{tabular}

Dimensi Altruism pada karyawan hotel Best Western Premier La Grande Bandung menunjukan nilai yang sangat tinggi secara keseluruhan sehingga dapat dikatakan bahwa karyawan pada hotel tersebut memiliki antusiasme untuk membantu satu sama lain dan tidak mementingkan kepentingan pribadi dalam mencapai tujuan organisasi. contohnya adalah perilaku seperti membantu rekan kerja yang tidak masuk kerja, membantu rekan kerja yang memiliki beban kerja berat (overload), memperhatikan perilaku seseorang memengaruhi pekerjaan orang lain, dan menyediakan bantuan dan dukungan untuk karyawan baru.

2. Tingkat Conscientiousness Karyawan Hotel Best Western Premier La Grande Bandung

\section{Tabel 4}

Tingkat Conscientiousness

\begin{tabular}{lc}
\hline Indikator Conscientiousness & Rata - Rata \\
\hline $\begin{array}{l}\text { Datang lebih awal, sehingga siap bekerja pada saat jadwal } \\
\text { kerja dimulai. }\end{array}$ & 4.55 \\
\hline $\begin{array}{l}\text { Tepat waktu setiap hari tidak peduli pada musim ataupun lalu } \\
\text { lintas, dan sebagainya }\end{array}$ & 4.60 \\
\hline
\end{tabular}




\begin{tabular}{lc}
\hline Berbicara seperlunya dalam percakapan di telepon. & 4.05 \\
\hline $\begin{array}{l}\text { Tidak menghabiskan waktu untuk pembicaraan diluar } \\
\text { pekerjaan. }\end{array}$ & 4.23 \\
\hline Datang segera jika dibutuhkan. & 4.53 \\
\hline $\begin{array}{l}\text { Tidak mengambil kelebihan waktu meskipun memiliki ekstra 6 } \\
\text { hari. }\end{array}$ & 4.33 \\
\hline \multicolumn{2}{c}{ Total Conscientiousness } \\
\hline
\end{tabular}

\section{Sumber: Hasil Pengolahan Data}

Dimensi Conscientiousness pada karyawan Hotel Best Western Premier La Grande Bandung menunjukan nilai yang sangat tinggi secara keseluruhan sehingga dapat dikatakan bahwa karyawan di hotel tersebut berdedikasi untuk bekerja dan mencapai hasil diatas standar yang ditetapkan dapat ditunjukkan dengan melakukan pekerjaan melebihi apa yang diharapkan perusahaan. Mereka sadar akan tanggung jawabnya secara sukarela mengambil tanggung jawab ekstra dengan selalu bekerja tepat waktu, menempatkan kepentingan pada keterperincian dan kualitas tugas, dan secara umum mengerjakan di atas dan jauh melebihi tanggung jawab tugas dan harapan, bekerja sepanjang hari, tidak membuang-buang waktu, mentaati semua peraturan perusahaan, secara sukarela bersedia melakukan pekerjaan yang tidak menjadi tanggungjawabnya

3. Tingkat Sportmanship Karyawan Hotel Best Western Premier La Grande Bandung

Tabel 5

Tingkat Sportmanship

\begin{tabular}{lc}
\hline Indikator Sportmanship & Rata - Rata \\
\hline Tidak menemukan kesalahan dalam organisasi. & 4.15 \\
\hline Tidak membesar-besarkan permasalahan diluar proporsinya. & 4.43 \\
\hline $\begin{array}{l}\text { Tidak memprovokasi karyawan lain untuk bertindak melawan } \\
\text { organisasi }\end{array}$ & 4.52 \\
\hline $\begin{array}{l}\text { Menjalankan tugas tanpa complain dan mengeluh } \\
\text { Menerima kebijakan ataupun aturan baru yang diterapkan } \\
\text { organisasi }\end{array}$ & 4.43 \\
\hline \multicolumn{2}{c}{ Total Sportmanship } \\
\hline
\end{tabular}

Sumber: Hasil Pengolahan Data

Dimensi Sportmanship pada karyawan hotel Best Western Premier La Grande Bandung menunjukan nilai yang sangat tinggi secara keseluruhan sehingga dapat dikatakan bahwa karyawan di hotel tersebut memberikan toleransi terhadap keadaan yang kurang ideal dan kurang sesuai dalam organisasi tanpa mengajukan keberatan-keberatan.

Contoh perilakunya antara lain perilaku untuk bertoleransi tanpa mengeluh, menahan diri dari aktivitas-aktivitas mengeluh dan mengumpat karena adanya 
ketidaksesuaian dalam organisasi atau perusahaan, tidak mencari-cari kesalahan dalam organisasi, dan tidak mengeluh tentang segala sesuatu, tidak memprovokasi rekan kerja untuk menuntut hal-hal yang tidak sesuai serta tidak membesar-besarkan permasalahan di luar proporsinya.

4. Tingkat Civic Virtue Karyawan Hotel Best Western Premier La Grande Bandung

Tabel 6

\section{Tingkat Civic Virtue}

\begin{tabular}{lc}
\hline Indikator Civic Virtue & Rata - Rata \\
\hline $\begin{array}{l}\text { Memberikan perhatian terhadap fungsi-fungsi yang membantu } \\
\text { image organisasi. }\end{array}$ & 4.42 \\
\hline $\begin{array}{l}\text { Memberikan perhatian terhadap pertemuan-pertemuan yang } \\
\text { dianggap penting. }\end{array}$ & 4.38 \\
\hline Membantu mengatur kebersamaan secara departemental. & 4.50 \\
\hline $\begin{array}{l}\text { Berpartipasi dalam setiap acara yang diadakan perusahaan. } \\
\text { Mengikuti perubahan-perubahan dan perkembangan- }\end{array}$ & 4.35 \\
$\begin{array}{l}\text { perkembangan dalam organisasi. } \\
\text { Membaca dan mengikuti pengumuman-pengumuman organisasi. }\end{array}$ & 4.37 \\
\hline $\begin{array}{l}\text { Membuat pertimbangan dalam menilai apa yang terbaik untuk } \\
\text { organisasi }\end{array}$ & 4.30 \\
\hline \multicolumn{2}{c}{ Total Civic Virtue } \\
\hline
\end{tabular}

Dimensi Civic Virtue pada karyawan hotel Best Western Premier La Grande Bandung menunjukan nilai yang sangat tinggi secara keseluruhan sehingga dapat dikatakan bahwa karyawan di hotel tersebut memiliki tanggung jawab pada kehidupan organisasi (bersedia mengikuti atau mentaati perubahan-perubahan yang terjadi dalam perusahaan, mengambil inisiatif untuk merekomendasikan bagaimana operasi atau prosedur-prosedur organisasi dapat diperbaiki dan melindungi sumber-sumber yang dimiliki oleh organisasi)

5. Tingkat Courtesy Karyawan Hotel Best Western Premier La Grande Bandung

Tabel 7

Tingkat Courtesy

\begin{tabular}{lc}
\hline Indikator Courtesy & Rata - Rata \\
\hline Menghormati perbedaan antara rekan kerja & 4.67 \\
\hline Bersosialisasi dengan rekan kerja antar departemen lain & 4.73 \\
\hline $\begin{array}{l}\text { Memberitahu atau mengajarkan rekan kerja cara kerja yang } \\
\text { efektif dan sesuai dengan SOP }\end{array}$ & 4.55 \\
\hline \begin{tabular}{l} 
Meminta maaf jika membuat kesalahan terhadap rekan kerja \\
\hline $\begin{array}{l}\text { Mengkomunikasikan segala sesuatu jika terjadi permasalahan } \\
\text { antar rekan kerja }\end{array}$
\end{tabular} \\
\hline \multicolumn{2}{c}{ Total Courtesy } \\
\hline \multicolumn{2}{c}{ Sumber: Hasil Pengolahan Data } \\
\hline
\end{tabular}


Dimensi Courtesy pada karyawan hotel Best Western Premier La Grande Bandung menunjukan nilai yang sangat tinggi secara keseluruhan sehingga dapat dikatakan bahwa karyawan di hotel tersebut selalu berusaha menjaga hubungan baik dengan rekan kerjanya agar terhindar dari masalah interpersonal. Dan dari ke lima dimensi yang ada, dimensi courtesy menjadi dimensi yang memiliki nilai rataan paling tinggi. Tingkat menghargai dan perhatian dinilai karyawan hotel Best Western Premier La Grande Bandung merupakan hal yang mereka utamakan dalam membangun hubungan antar karyawan.

\section{Kesimpulan}

Berdasarkan hasil penelitian yang telah dilakukan kepada karyawan Best Western Premier La Grande Hotel Bandung menunjukan bahwa tingkat Organizational Citizenship Behavior karyawan hotel tersebut sangat tinggi. Terlihat dari skor rata-rata setiap dimensinya antara lain: Altruism (4.25), Conscientiousnes (4.38), Sportmanship (4.39), Civic Virtue (4.39) dan Courtesy (4.63). Skor rata-rata tertinggi pada dimensi Courtesy menunjukan bahwa karyawan hotel memiliki relasi yang baik dan sangat menjaga hubungan interpersonal tersebut untuk menghindari terjadinya konflik dengan sesama rekan kerjanya. Organizational Citizenship Behavior yang dikelola dengan baik akan membawa dampak positif baik bagi karyawan maupun bagi perusahaan. Dampak positif bagi karyawan antara lain: meningkatnya kepuasan kerja, produktivitas kerja, motivasi kerja hingga keterikatan karyawan baik pada pekerjaan, rekan kerja maupun pada perusahaan. Hal ini juga dapat mencegah keinginan karyawan untuk keluar (intensi turn over), sehingga perusahaan tidak perlu mengeluarkan biaya-biaya lain untuk perekrutan dan pelatihan karyawan baru. Selain itu, tingkat Organizational Citizenship Behavior yang tinggi pada karyawan akan meningkatkan pelayanan terbaik (service excellent) pada tamu, sehingga secara tidak langsung pelayanan yang baik akan membuat tamu tidak segan untuk kembali menginap di hotel. Hal ini tentunya akan membawa profit bagi hotel. Semakin tinggi tingkat Organizational Citizenship Behavior karyawan, maka akan semakin tinggi pula produktivitas perusahaan.

Penelitian ini memberikan beberapa pemikiran untuk pengembangan ilmu pengetahuan di kemudian hari, khususnya terkait Organizational Citizenship Behavior yang jarang dilakukan penelitian di Indonesia. Namun, penelitian ini masih memiliki banyak keterbatasan yang perlu diperhatikan untuk kepentingan penelitian mendatang, antara lain: jumlah responden masih relatif sedikit $(\mathrm{N}=60)$ dan hanya terbatas pada satu perusahaan saja, penelitian berikutnya hendaknya mampu mengambil jumlah responden yang cukup banyak sehingga bisa mewakili populasi yang ada. Selain itu, penelitian ini belum mampu menggambarkan fenomena Organizational Citizenship Behavior dengan jelas karena keterbatasan metode yang digunakan, sehingga disarankan untuk penelitian selanjutnya dapat menggunakan metode penelitian yang lebih mampu menjelaskan fenomena tersebut. 


\section{BIBLIOGRAFI}

Abtahi, M. (2014). A study on how organizational citizenship behavior influences on human resource management. Management Science Letters, 4(3), 555-558.

Dominic, P. D. D., Goh, K. N., Wong, D., \& Chen, Y. Y. (2010). The importance of service quality for competitive advantage-with special reference to industrial product. International Journal of Business Information Systems, 6(3), 378-397.

Fitriyana, D. 2015. Konflik Pengelolaan Ekowisata Berbasis Pemberdayaan Masyarakat di Taman IR. H. Djuanda Bandung, Jawa Barat. Master Thesis, Universitas Udayana. Diakses dari https://erepo.unud.ac.id/id/eprint/638/

George, G., \& Joseph, B. (2015). A study on the relationship between Employee engagement and organizational citizenship with reference to employees working in travel organizations. Atna Journal of Tourism Studies, 10(2), 33-44.

Hemaloshinee, V., \& Nomahaza, M. (2017). Organizational citizenship behavior in hospitality industry: Bridging challenges, benefits and contribution. Int. J. Hum. Capital Urban Managent, 2(3), 243-250.

Husniati, R., \& Pangestuti, D. C. (2019). Organizational citizenship behavior (OCB) pada pegawai UPN "Veteran" Jakarta. Jurnal Bakti Masyarakat Indonesia, 1(1), $234-242$.

Maywati, Rima. 2019. Perancangan Wind Tunnel Hotel di Bandung Dengan Pendekatan Konsep Rumah Rayap. Skripsi Thesis, Institut Teknologi Nasional Bandung. Diakses dari http://eprints.itenas.ac.id/462/

Moorhead, G., \& Griffin, R. W. (2013). Perilaku Organisasi: Manajemen Sumber Daya Manusia dan Organisasi. Jakarta: Salemba Empat.

Olowookere, E. I., \& Adejuwon, G. A. (2015). Development and Validation of Organizational Citizenship Behaviours Scale (OCBS) for the Nigerian Context. Psychology, 6(05), 533.

Pradana, M., Fakhri, M., Gilang, A., \& Khairin, P. (2018). Determinants of Organizational Citizenship Behavior: The Case of an Indonesian Insurance Company. Jurnal Bisnis dan Manajemen, 19(2), 88-100.

Ratnayaka, R. M., Kumara, P. A. P. S., \& Silva, MWSW. (2020). Impact of Organizational Citizenship Behavior on Perceived Service Quality in Hotel Industry. Journal of the University of Ruhuna, 7(1), 25 - 42.

Robbins. S. P., \& Jugde, T. A. (2015). Perilaku Organisasi (Organizational Behavior) Edisi 16. Jakarta: Salemba Empat.

Sanusi, A. C., Ariana, N. \& Ariani, N. M. (2018). Tingkat Organizational Citizenship 
Behavior (Ocb) Karyawan di Four Points Seminyak. Jurnal Kepariwisataan Dan Hospitalitas. 2(1), 61-83.

Singh, A. K., \& Singh, A. P. (2010). Role of stress and organizational support in predicting organizational citizenship behavior. IUP Journal of Organizational Behavior, 9(4), 7 -25.

Sugiyono. (2013). Metode Penelitian Kuantitatif Kualitatif R\&B. Bandung: Aflabeta.

Sugiyono. (2015). Metode Penelitian Administrasi. Bandung: Aflabeta.

Triyanto, Agus. (2009). Organizational citizenship behavior (OCB) dan pengaruhnya terhadap keinginan keluar dan kepuasan kerja karyawan. Jurnal Manajemen Maranatha, 8(2), 52-65. 